\title{
JURČÁK, Vojtech a kol. Teoretické prístupy $k$ skúmaniu bezpečnosti. Ostrava: KEY Publishing, 2020. ISBN 978-80-7418-358-4. 134 s.
}

\section{Petr Rožňák}

Monografie autorského kolektivu pod vedením prof. Vojtecha Jurčáka, vedoucího Katedry bezpečnosti a obrany Akadémie ozbrojených síl generála Milana Rastislava Štefánika $v$ Liptovském Mikuláši je jednou z nemnohých publikací, rozšiřující obzor vědeckého bádání v oblasti výzkumu bezpečnosti. Podobných publikací, které vznikají ve slovenském prostředí, $v$ českém odborném tisku nenalezneme mnoho. Podle mého názoru, autoři kolektivní vědecké monografie Teoretické prístupy $k$ skúmaniu bezpečnosti vycházející tiskem péčí moravského vydavatelství a nakladatelství KEY Publishing, disponují obrovským potenciálem poznatků z dané oblasti a poskytují čtenáři konstruktivní pohled na problematiku zkoumání bezpečnosti.

Monografie je určena primárně odborníkům dané oblasti, ale je napsána tak srozumitelně, že si ji mưže snadno přečíst na „jeden zátah“ i laický čtenář. Je prostým faktem, že v české odborné literatuře tiskem podobné ucelené dílo slovenských autorů dosud chybí. Vojtech Jurčák, Pavel Bučka, Marek Hargaš, Mária Machynová, Tomáš Martaus, Lenka Nagyová, Miroslav Sedlák, Milan Turaj a Michal Varga přicházejí se svou monografií $v$ době nejhlubší krize evropského společenství (a dost možná i NATO Severoatlantická aliance) od počátku celého integračního procesu. Evropa stále čelí bezprecedentní imigrační vlně a Evropská unie se vưči tomu zdá být i nadále, a to přes veškerou snahu národních států, zcela bezmocná, politicky i vojensky, alespoň si to myslí dle řady průzkumů $v$ jednotlivých státech velká část evropské populace. Euroamerická finanční a ekonomická krize rovněž odhalila neudržitelnost situace eurozóny („brexit“ je dost možná počátkem „dominového“ efektu a počátečním signálem proměn EU - Evropská unie). Prezidentské volby v USA (Spojené státy severoamerické) a zatvrzelé setrvávání na politických stereotypech $k$ jednotnosti Spojených států nepřispěly. Život obyvatel Země sužuje, svírá a ovlivňuje celosvětová pandemie COVID 19. Celosvětově je potvrzených př́padů napadených virem COVID 19 celkem 49951976 osob a prokázána smrtnost 1255831 (data aktuálně k 9.11.2020). Hrozí kolaps zdravotnictví. Dopady do české i slovenské společnosti jsou v rovině sociální, ekonomické a bezpečnostní obrovské. Zmiňovat tyto souvislosti na počátku recenze knihy není v tomto prípadě samoúčelné, jak by se možná na první pohled mohlo zdát. Jurčák a kol. přicházejí se svou monografií v tomto okamžiku a ve chvíli, kdy řada mechanismů ve vojenství a dříve zdánlivě nepřekročitelných zásad a pravidel podléhá aktuální vážnosti situace a ad hoc politickým rozhodnutím. Autoři mají zcela jistě pravdu, když na s. 12 tvrdí, že:

\footnotetext{
${ }^{a}$ Department of Security and Law, AMBIS, a.s. Brno, Czech Republic. petr.roznak@gmail.com. Researcher ID: 0000-0003-1714-3457.
} 
„....bezpečnost' je istota, kedy na životne dôležité hodnoty referenčného objektu deštruktívne nepôsobia žiadne entity, subjekty, procesy a to ako v rámci referenčného objektu, tak i v jeho okolí."

Přičemž dokládají (tamtéž), že:

„Referenčný objekt je objekt, ku ktorému vzt'ahujeme bezpečnost'. Referenčným objektom môže byt' osoba, skupina ludí, spoločnost', štát, skupina štátov, svetadiel, ludstvo, svet, systémy prirodzeného i umelého prostredia (príroda, odvetvia spoločenskej, hospodárskej, vojenskej, politickej činnosti).“

Logicky je to vede $\mathrm{k}$ tomu, že se zabývají př́stupem jednotlivých teorií zkoumání bezpečnosti. Vycházejí přitom z historie potřeby zajištění bezpečnosti států, jak ukázaly dlouhodobé války vedené $v$ Evropě i ve světě, které přinesly jen velké oběti, materiální škody, utrpení bohužel hlad a bídu. Správně totiž poukazují na to, že se na prahu 21. století, mění zásadním způsobem způsob vedení války, která je hybridní a krutější, ale zároveň zákeřnější (ISIS - tzv. Islámský stát v Iráku a Sýrii). Bezpečnostní rizika se dynamicky a poměrně rychle proměňují. Text monografie je rozčleněn do sedmi základních bloků a celé řady vhodně zařazených podkapitol (podbodů). Autoři monografie dokázali svou erudici $v$ řadě oblastí, jejichž společným jmenovatelem je dodržení linie, a hlavního cíle avizovaného již samotným jejím názvem, která prolíná celou monografií. Těžko říci, kterou oblast upřednostnit. 1. Význam Európskeho koncertu a Viedenského kongresu na formovanie agendy bezpečnosti. 2. Teória realizmu a jej prístup k skúmaniu bezpečnosti. 3. Teória liberalizmu a jej prístup k skúmaniu bezpečnosti. 4. Teória konštruktivizmu a jej prístup k skúmaniu bezpečnosti. 5 . Kritické teórie a ich prístup $\mathrm{k}$ skúmaniu bezpečnosti. 6 . Princíp sebaurčenia a princíp územnej celistvosti $v$ kontexte teórie princípov Roberta Alexyho. 7. Vývoj bezpečnosti od ukončenia bipolárneho usporiadania sveta až do súčasnosti. Prezentované bloky představují vědecký, jakož i odborně zpracovaný materiál a znamenají př́nos pro zvýšení bezpečnostního povědomí v komunitě odborníků na Bezpečnost. Vyzdvihnout je třeba interdisciplinární charakter jednotlivých bloků. Za př́nosný považuji zejména blok pátý Kritické teórie a ich prístup k skúmaniu bezpečnosti a blok sedmý Vývoj bezpečnosti od ukončenia bipolárneho usporiadania sveta až do súčasnosti postihujících základní aktuální teoretické př́stupy ke zkoumání bezpečnosti. Monografie je přínosem $\mathrm{k}$ rozvoji vědeckého bádání nejen $v$ oboru národní a mezinárodní bezpečnost, ale mezinárodních vztahů, práva, politologie i filozofie. Autoři se nevyhýbají ožehavým tématům. $V$ textu knihy jsem neshledal žádná faktická pochybení. Autoři monografie se snaži plynule a s logickou posloupností provázet čtenáře $v$ jednotlivých částech knihy základními teoretickými prístupy zkoumání bezpečnosti včetně jejich postupného vývoje a je na místě konstatovat, že se jim to daří. Jde o text mimořádného významu, který by neměl zůstat bez povšimnutí vojenské, vědecké, ale i laické obce. Př́nos této monografie spočívá v možnosti jejího dalšího využití primárně ve vojenském školství, ale také katedrách bezpečnosti, práva a politologie českých a slovenských univerzit a vysokých škol. Zjištěné a prezentované skutečnosti předkládané čtenáři $v$ této monografii svým významem přesahují dosud dostupné práce. Jsem přesvědčen, že autory provedená hluboká analýza stavu dané oblasti, a jimi získané vojensko-odborné poznatky, překračují hranice bratrského Slovenska a jsou jednoznačně upotřebitelné pro 
další partnerské armády a členské země Evropské unie a NATO. Silnou stránkou autorů je skvělá stylistika, výběr vhodných termínů, a jestliže $k$ tomu přidáme přehledné citace s patřičnými komentáři, vzniklo zde pozoruhodné dílo. 
